\title{
KATARZYNA KOKOCIŃSKA
}

ORCID: 0000-0002-1008-3538

Uniwersytet im. Adama Mickiewicza w Poznaniu

katarzyna.kokocinska@amu.edu.pl

\section{Działania państwa na rzecz rozwoju przedsiębiorczości - ujęcie normatywne, funkcjonalne i strukturalne}

\begin{abstract}
Abstrakt: Uzasadnieniem podjęcia problematyki aktywności państwa w sferze rozwoju przedsiębiorczości, zagadnienia analizowanego najczęściej w ujęciu funkcji administracji publicznej w gospodarce, są intensywność i zakres wprowadzanych zmian. Celem opracowania jest wykazanie, że przyjęta polityka państwa na rzecz rozwoju wywołuje określone konsekwencje zarówno w sferze normatywnej, jak i funkcjonalnej, a przede wszystkim w strukturach administracji publicznej. Nowe rozwiązania organizacyjne i funkcjonalne w administracji publicznej wdrażane są jako efekt zabiegów na rzecz usprawnienia działania i budowania administracji racjonalnej. Kształtowanie nowego modelu administracji bądź jego reorganizacja pod hasłem administracji odpowiedniej do społeczno-gospodarczych potrzeb wymaga jednak uwzględnienia podstawowych założeń ustrojowych.
\end{abstract}

Słowa kluczowe: wspieranie rozwoju przedsiębiorczości, funkcja państwa w gospodarce, rozwój społeczno-gospodarczy, administracja sieciowa, instytucje rozwoju.

\section{Wprowadzenie. Polityka państwa na rzecz rozwoju przedsiębiorczości}

Podjęcie problematyki aktywności państwa w sferze rozwoju przedsiębiorczości, zagadnienia analizowanego najczęściej w ujęciu funkcji administracji publicznej w gospodarce ${ }^{1}$, uzasadniają wprowadzane do krajowego systemu prawnego re-

1 Na temat funkcji państwa w gospodarce zob. System Prawa Administracyjnego, red. R. Hauser, Z. Niewiadomski, A. Wróbel, t. 8a. Publiczne prawo gospodarcze, Warszawa 2018, s. 653 n. oraz wskazywaną tam literaturę. 
gulacje będące wyrazem aktualnej polityki państwa, normatywnie określanej jako polityka rozwoju ${ }^{2}$. Ich wielość, a także intensywność i zakres wymaga szerszego spojrzenia - analizy uwzględniającej aspekt normatywny, funkcjonalny i strukturalny.

Punktem wyjścia prowadzonych rozważań jest polityka władzy publicznej traktowana w piśmiennictwie jako „określenie najbardziej efektywnych, prawem dopuszczonych sposobów działania administracji w osiągnięciu celów publicznych, sposobów dopuszczalnych w istniejących uwarunkowaniach prawnych"3. Chodzi zatem o „optymalne ujęcie prawnego wyrazu polityki państwa”" .,Prowadzenie polityki" odnoszone jest do działań na rzecz rozwoju. Podobnie jak w wypadku ,polityki” „,rozwój” jest trudną do uchwycenia kategorią znaczeniową ${ }^{5}$. Oba te zjawiska (polityka i rozwój) nie są bowiem pozbawione aksjologii; stanowią wyraz bądź wynik działań osób reprezentujących pewne wartości i kierujących się określonymi normami prawnymi, bądź pozaprawnymi lub akceptowanymi przez daną grupę regułami postępowania ${ }^{6}$. Dlatego politykę należy traktować jako wartościowanie i ustalanie kryteriów potrzeb społecznych w obszarze stosunków społecznych i gospodarczych, objętych działalnością administracji publicznej $^{7}$. Tak rozumiana polityka znajduje ostatecznie bezpośrednie odniesienie w aktach prawodawczych ${ }^{8}$, wpływając także na wartości ujęte w normach prawnych ${ }^{9} . \mathrm{Z}$ tego powodu analizę obowiązującego porządku normatywnego należy

2 Zgodnie z ustawą z dnia 6 grudnia 2006 roku o zasadach prowadzenia polityki rozwoju (tekst jedn. Dz.U. z 2019 r. poz. 1295). Na ten temat zob. K. Kokocińska, Prawny mechanizm prowadzenia polityki rozwoju $w$ zdecentralizowanych strukturach władzy publicznej, Poznań 2014, s. 309.

3 J. Jeżewski, Polityka administracyjna. Zagadnienia podstawowe, [w:] A. Błaś, J. Boć, J. Jeżewski, Administracja publiczna, red. J. Boć, Wrocław 2003, s. 309.

${ }^{4}$ M. Kulesza, Z problematyki badań nad metodami dziatania administracji, [w:] Zbiór studiów z zakresu nauk administracyjnych, red. Z. Rybicki, M. Gromadzka-Grzegorzewska, M. Wyrzykowski, Wrocław 1978, s 337. Należy tu poczynić zastrzeżenie, że jest to modelowe ujęcie relacji prawa polityki do prawa, albowiem w praktyce w celu realizacji polityki państwa uwarunkowania prawne często są dostosowywane do jej celów.

5 Zob. P. Churski, Czynniki rozwoju regionalnego i polityka regionalna $w$ Polsce $w$ okresie integracji z Unia Europejska, Poznań 2008, s. 26.

6 Odwoływanie się do określonych wartości, norm prawnych i pozaprawnych, reguł postępowania według J. Hausnera jest niezbędne, albowiem ,nieprzestrzeganie praw politycznych i demokratycznych reguł w długiej perspektywie blokuje rozwój — między innymi dlatego, że oznacza pozbawienie jednostek i grup niezbędnej autonomii, a społeczeństwa obywatelskiego podmiotowości” — idem, Zarządzanie publiczne, Warszawa 2008, s. 370.

7 Za: T. Bigo, Prawo administracyjne. Część ogólna, Lwów 1932, s. 2.

${ }^{8} \mathrm{~K}$. Kokocińska, Istota aktów programowania rozwoju jako instrumentów oddziaływania państwa na gospodarkę, [w:] Administracja a strategie i polityki publiczne, red. A. Jurkowska-Gomułka, Warszawa 2016, s. 25-37.

${ }^{9}$ K. Kokocińska, Spoleczna gospodarka rynkowa - komplementarność, równowaga czy przewaga wartości? Uwagi na tle działań państwa w zakresie prowadzenia polityki rozwoju, „Gdańskie Studia Prawnicze" 37, 2017, s. 27-36. 
uzupełniać badaniami nad polityką państwa ${ }^{10}$ (i Unii Europejskiej ${ }^{11}$ ), która rozstrzyga o kluczowych obszarach systemu społeczno-gospodarczego ${ }^{12}$.

Aktualne cele, których osiągnięcie jest konieczne z punktu widzenia założeń rozwoju kraju, zostały określone w Strategii na rzecz odpowiedzialnego rozwoju do roku $2020^{13}$. Strategia ta zakłada między innymi, że zmiany ustawodawcze mają stanowić jeden z podstawowych elementów przebudowy i reformy instytucjonalnej otoczenia przedsiębiorców. Akcentowana w strategii potrzeba zwiększenia odpowiedzialności instytucji państwa za kształtowanie procesów gospodarczych, społecznych i terytorialnych przy zachowaniu konstytucyjnego modelu społecznej gospodarki rynkowej ma uzasadniać aktywność państwa w kreowaniu warunków do rozwoju (w podejmowaniu działań służących wspieraniu wzrostu gospodarczego $)^{14}$.

Potwierdza to istotność badań w obszarze regulacji prawnych stanowiących wynik założeń polityki rozwoju społeczno-gospodarczego państwa, jej oddziaływania na procesy związane z rozwojem gospodarki, w tym z rozwojem działalności gospodarczej. Polityka wpływa również na kształtowanie i funkcjonowanie administracji publicznej, dlatego zagadnienie to wymaga podejścia wieloaspektowego - ujęcia tego zjawiska z punktu widzenia oddziaływania w warstwie normatywnej, a także w płaszczyźnie strukturalnej i funkcjonalnej.

10 Polityka jako przedmiot badań jest wśród nauk administracyjnych domeną nauki polityki administracyjnej, zajmującej się optymalizacją skuteczności działalności publicznej, czyli jej sprawnością - H. Izdebski, M. Kulesza, Administracja publiczna. Zagadnienia ogólne, Warszawa 2004, s. 351. J. Jeżewski podkreśla, że treścią polityki administracyjnej jest wskazanie najbardziej przydatnej metody regulacji prawnej w określonej dziedzinie, a także „określenie najbardziej efektywnych, prawem dopuszczonych sposobów działania administracji w osiągnięciu celów publicznych" — idem, op. cit., s. 309. Zob. także G. Rydlewski, Polityka i administracja w rzadach państw członkowskich Unii Europejskiej, Warszawa 2006; P.J. Suwaj, R. Szczepankowski, Wokót pojęcia polityki publicznej, [w:] Nauka administracji, red. B. Kudrycka, B.G. Peters, P.J. Suwaj, Warszawa 2009, s. 305; P.J. Suwaj, Polityka publiczna jako instrument administrowania, [w:] Nauka administracji..., s. 308.

11 D.M. Trubek, P. Corttel, M. Nance, ,Soft law”, ,hard law” and EU integration, [w:] New Governance and Constitutionalism, red. J. Scott, G. de Burca, Oxford 2005, s. 65 n. Aktualnie cele te wyznacza komunikat Komisji EUROPA 2020, Strategia na rzecz inteligentnego i zrównoważonego rozwoju sprzyjającego włączeniu społecznemu, Bruksela 3 marca 2010, KOM (2010) 2020, wersja ostateczna.

12 M. Kulesza podkreśla związek polityki z prawem, wskazując, że ,istota polityki administracyjnej polega przede wszystkim na ustaleniu najbardziej w danej dziedzinie przydatnych (skutecznych) metod regulacji prawnej i określeniu najefektywniejszych sposobów działania administracji, sposobów dopuszczalnych w istniejących uwarunkowaniach prawnych. Chodzi zatem o optymalne ujęcie prawnego wyrazu polityki państwa" - idem, op. cit., s. 337.

13 Uchwała numer 8 Rady Ministrów z dnia 14 lutego 2017 roku w sprawie przyjęcia Strategii na rzecz odpowiedzialnego rozwoju do roku 2020 (z perspektywą do 2030 roku); dalej: SOR.

14 SOR, s. 35 n. 


\section{Aspekt normatywny}

Istotne znaczenie dla podjętej problematyki, oprócz przyjętej koncepcji oddziaływania państwa na gospodarkę, ma jej legislacyjny wyraz. Uzasadnia to prowadzenie analiz obowiązujących przepisów prawa z punktu widzenia celów polityki państwa, których efektem są między innymi zadania publiczne, formalna organizacja administracji publicznej, a także prawnie określone zasady organizacji jej działania.

Dokonując oceny regulacji normatywnych we współczesnych demokratycznych państwach o gospodarce rynkowej, coraz częściej wskazuje się na kryzys prawa, jego inflację ${ }^{15}$, ,rozwodnienie" mocy obowiązującej ${ }^{16}$. Regulacja administracyjna - hard law - coraz częściej uzupełniana jest przez soft law (na przykład w ramach mechanizmu samoregulacji ${ }^{17}$ ). Instrumenty soft law bowiem ,przesuwają prawo poza jego tradycyjne granice" 18 . Oficjalne standardy, kodeksy dobrych praktyk, prawo do dobrej administracji to standardy „funkcjonujące” (nie zaś obowiązujące) na zasadzie autorytetu tego, kto je przyjął. System regulacji dodatkowo komplikują akty polityki państwa - strategie rozwoju, plany, programy, koncepcje o niejednorodnym charakterze prawnym ${ }^{19}$.

Należy zwrócić uwagę na zmianę charakteru ustawodawstwa, zjawisko umniejszania znaczenia ustawodawstwa stabilnego, generalnego i precyzyjnego, przy jednoczesnym zwiększeniu znaczenia prawa, które jest reakcją na określone uwarunkowania społeczno-gospodarcze, stanowiące często odpowiedź na aktualną politykę państwa w danym obszarze gospodarki. Nie oznacza to, że zmiany w ustawodawstwie (szczególnie gospodarczym) nie są pożądane. Regulacje prawa publicznego, którego przedmiotem normowania są stosunki gospodarcze, odzwierciedlają zachodzące przemian, odpowiadają na zmieniające się uwarunkowania społeczne i ekonomiczne. Choć w naturę prawa publicznego wpisana jest ciągła jego przebudowa, to jednak zmiany ustawodawstwa gospodarczego powinny zapewniać stabilizację sytuacji prawnej uczestników obrotu gospodarczego; powin-

15 Zob. Kryzys prawa administracyjnego, t. 2. Inflacja prawa administracyjnego, red. P.J. Suwaj, Warszawa 2012.

16 Zob. Kryzys prawa administracyjnego, t. 1. Jakość prawa administracyjnego, red. D.R. Kijowski, A. Miruć, A. Suławko-Karetko, Warszawa 2012.

17 Zob. m.in. M. Fedorowicz, Kilka uwag o zjawisku samoregulacji na rynku bankowym w nowej architekturze nadzorczej, „Studia Administracyjne Uniwersytetu Szczecińskiego” 2018, nr 10, s. $113-128$.

18 K. Strzyczkowski, Uwagi o zadaniach nauki o prawnych formach dziatania administracji gospodarczej, [w:] Instrumenty i formy prawne działania administracji gospodarczej, red. B. Popowska, K. Kokocińska, Poznań 2009, s. 35.

19 Zob. K. Kokocińska, Istota aktów programowania rozwoju jako instrumentów oddziaływania państwa na gospodarkę, [w:] Administracja a strategie i polityki publiczne, red. A. Jurkowska-Gomułka, Warszawa 2016, s. 25-37. 
ny w sposób jednoznaczny stanowić o roli państwa w gospodarce i zakresie jego oddziaływania (w tym ingerencji w stosunki gospodarcze), przy jednoczesnym wyznaczaniu pozycji obywateli i ich praw ekonomicznych.

Innym kluczowym zagadnieniem stosowania publicznego prawa gospodarczego ,jest właściwy dobór — najogólniej mówiąc — instrumentów działań podejmowanych przez organy administracji publicznej (i inne podmioty publiczne), na które prawo to nakłada określone zadania" ${ }^{20}$. Konieczne jest też odpowiednie ustalanie zakresu zadań publicznych, właściwych kompetencji organów administracji publicznej do ich wykonywania, czyli właściwej organizacji administracji publicznej (o czym dalej), przy czym działania te należy każdorazowo odnosić do całości systemu prawa. Istotne jest zachowanie ciągłości konstrukcji prawnych ${ }^{21}$.

Wszystkie te czynniki należy uwzględniać, formułując oceny na temat stanu krajowego ustawodawstwa mającego za przedmiot normowania działania państwa na rzecz wspierania rozwoju przedsiębiorczości. To właśnie w tym obszarze ustawodawca krajowy jest szczególnie aktywny. Świadczy o tym przyjęty w 2018 roku pakiet ustaw określany w SOR mianem konstytucji biznesu, w tym ustawa z dnia 6 marca 2018 roku Prawo przedsiębiorców, uznany przez polski rząd za projekt strategiczny ${ }^{22}$, a także inne regulacje będące wynikiem polityki rozwoju ukierunkowanej na przedsiębiorczość, do których należy zaliczyć między innymi ustawę z dnia 10 maja 2018 roku o wspieraniu nowych inwestycji ${ }^{23}$ oraz pakiet Przyjazne Prawo - ustawę z dnia 31 lipca 2019 o zmianie niektórych ustaw w celu ograniczenia obciążeń regulacyjnych ${ }^{24}$.

\section{Ujęcie funkcjonalne}

Ma to też odniesienie do rozważań na temat zmiany roli państwa w gospodarce - $\mathrm{w}$ analizowanym przypadku do wspierania rozwoju przedsiębiorczości lub inaczej wspierania działalności gospodarczej (wspierająca funkcja państwa). Takie ujęcie znajduje swoje odwierciedlenie w kluczowej dla publicznoprawnych

20 T. Rabska, Działania administracji publicznej w świetle współczesnej koncepcji publicznego prawa gospodarczego, [w:] Instrumenty i formy prawne..., s. $27 \mathrm{n}$.

21 Ibidem, s. 24 n.

22 Konstytucja biznesu określana jest w SOR jako „nowy, spójny pakiet aktów prawnych całościowo regulujących zasady prowadzenia działalności gospodarczej w Polsce, który tworząc korzystne, przejrzyste i stabilne warunki do prowadzenia działalności gospodarczej, zapewnia pewność prawa, zmniejsza ryzyko biznesowe i zwiększa chęć przedsiębiorców do ponoszenia ryzyka technologicznego związanego z realizacją innowacyjnych projektów" (s. 225).

23 Dz.U. z 2018 r. poz. 115.

24 Dz.U. z 2019 r. poz. 1495. 
stosunków gospodarczych regulacji - ustawy z dnia 6 marca 2018 roku Prawo przedsiębiorców ${ }^{25}$.

Rozpatrując aktywność państwa w obszarze wspierania rozwoju przedsiębiorczości w ujęciu funkcjonalnym, jako wyjściową w tym zakresie należy traktować ustawę Prawo przedsiębiorców, mimo że ten akt prawny nie zawiera wyrażonego ustawowo zobowiązania organów administracji publicznej do prowadzenia działań na rzecz wspierania przedsiębiorczości. W preambule Prawa przedsiębiorców podkreśla się za to konieczność podejmowania działań ukierunkowanych na rozwój działalności gospodarczej. To państwo powinno bowiem zapewnić rozwój działalności w warunkach wolnej konkurencji, kierując się konstytucyjną zasadą wolności gospodarczej oraz innymi zasadami odnoszącymi się do sfery aktywności obywateli. Jednocześnie uwypukla się znaczenie i potrzebę ochrony oraz wspierania wolności działalności gospodarczej, które to działania przyczyniają się do rozwoju gospodarki oraz wzrostu dobrobytu społecznego. Ustawodawca nie rozstrzyga jednoznacznie zakresu normowania w obrębie tej sfery, akcentując, że wszelkie działania organów administracji publicznej objęte regulacją ustawy Prawo przedsiębiorców powinny być wykonywane z uwzględnieniem konieczności zapewnienia ciągłego rozwoju działalności gospodarczeje ${ }^{26}$.

Takie ujęcie wskazuje na bardzo szerokie traktowanie tej sfery oddziaływania administracji na stosunki gospodarcze ${ }^{27}$. Analiza przepisów ustawy w kontekście realizacji celu określonego przez ustawodawcę jako „ciągły rozwój działalności gospodarczej" prowadzi do wniosku, że to ustawowe określenie zachowań administracji publicznej mieści się w znanej i opisanej w doktrynie kategorii prawnej, jaką jest „wspieranie przedsiębiorczości”. Są to przy tym zarówno szczegółowe zadania organów administracji publicznej związane z realizacją typowych funkcji administracji w działalności gospodarczej, jak i ogólne normy postępowania w stosunkach z przedsiębiorcami.

Trzeba podkreślić, że wypełnianie funkcji wspierania gospodarki służy osiąganiu celów polityki państwa przez oddziaływanie na zachowanie przedsiębiorców, którzy tę politykę realizują.

Realizacja tej funkcji polega na wywieraniu w sposób niewiążący wpływu na kształtowanie porządku społeczno-gospodarczego poprzez udzielenie ze środków publicznych pomocy podmio-

25 Dz.U. z 2018 r. poz. 646.

${ }^{26}$ Szerzej na ten temat zob. K. Kokocińska, Wspieranie rozwoju działalności gospodarczej w ujęciu zasad i wartości, „Ruch Prawniczy, Ekonomiczny i Socjologiczny” (dalej: RPEiS) 2018, nr 4, s. 41-53.

27 „Ich wyrazem jest aktywność administracji publicznej wykonującej szczegółowe zadania; przykładowo w procedurze ewidencjonowania działalności gospodarczej, realizacji kompetencji związanych z reglamentacją działalności gospodarczej, koncesjonowaniem czy aktywnością Rzecznika MiSP. Innym, charakterystycznym i nowym (na tle dotychczasowych uregulowań), typem obowiązków organów administracji publicznej na rzecz rozwoju działalności gospodarczej są obowiązki określonego działania lub zaniechania działań wynikające z przepisów zawierających zasady postępowania organów administracji publicznej w relacjach z przedsiębiorcami” —ibidem, s. 51. 
tom prywatnym, co nierzadko związane jest dodatkowo z zobowiązaniem do postępowania zgodnie $\mathrm{z}$ uprzednio ustalonymi warunkami, w interesie publicznym ${ }^{28}$.

Państwo, stwarzając warunki do rozwoju działalności gospodarczej, stosuje instrumenty zachęcające przedsiębiorców do określonych, pożądanych przez nie zachowań realizujących cele polityki rozwoju społeczno-gospodarczego.

\section{Zagadnienia organizacji administracji gospodarczej na przykładzie systemu instytucji rozwoju}

Analizując politykę państwa w obszarze wspierania rozwoju przedsiębiorczości, należy spojrzeć na to zagadnienie z perspektywy celów polityki i jej oddziaływania na budowę i funkcjonowanie struktur administracji publicznej. Trzeba przy tym pamiętać, że pojęcie organizacji należy odnosić do kwestii strukturalnej w ujęciu statycznym (budowy), a także w ujęciu dynamicznym (zasad funkcjonowania).

Adresatem norm przepisów odnoszących się do wspierania przedsiębiorczości i jego rozwoju jest przede wszystkim (oprócz przedsiębiorców) administracja publiczna (administracja gospodarcza), która do właściwego wykonywania zadań publicznych wymaga odpowiedniej organizacji ${ }^{29}$. To zadania administracji publicznej determinują bowiem organizację administracji i jej metody działania.

Dotychczasowe diagnozy na temat przemian w obrębie struktur administracji publicznej wskazują głównie na zewnętrzne (w tym unijne, choć również globalne) uwarunkowania wywołujące skutki w sferze administrowania. W dużym uproszczeniu można przyjąć, że administracja publiczna nie uchroniła się przed jej europeizacją ${ }^{30}$, standaryzacją i nadal ulega ciągłym zmianom strukturalnym, zmierzając do wyznaczanego przepisami unijnymi modelu administracji unijnej. Procesy te zachodzą ze szczególną intensywnością w sektorach infrastrukturalnych: energetycznym, telekomunikacyjnym, transportowym, ale też w obszarach aktywności o charakterze bardziej uniwersalnym, jak prawo konkurencji czy polityka spójności. Obecnie charakteryzując struktury administracji publicznej, wskazuje się na postępujący proces konwergencji. Utożsamiany jest on ze zbliżeniem, a wręcz ujednolicaniem struktur administracji publicznej (jej aparatu) jako kolejnego etapu procesu europeizacji, który wymusił na władzach państw członkowskich tworzenie nowych organów, wyposażanych w nowe zadania i kompe-

28 Ibidem, s. 53.

29 T. Rabska, op. cit., s. 26.

30 I. Lipowicz, Europeizacja administracji publicznej, RPEiS 2008, nr 1, s. 5-17. 
tencje, bądź dostosowanie funkcjonującego aparatu administracji publicznej do wymogów wynikających z regulacji normatywnych.

Źródłem zmian w obrębie struktur administracji (budowy, zadań, kompetencji, instrumentów działań, w tym form współpracy) są często, o czym była wcześniej mowa, oprócz aktów normatywnych także akty samoregulacji wynikające z konieczności realizacji określonej polityki (unijnej, krajowej, branżowej, sektorowej). Skutkuje to powstawaniem szczególnych, skomplikowanych, wielopłaszczyznowych powiązań, nowych sposobów organizowania wykonywania zadań publicznych, zarówno od strony struktury organizacyjnej, jak i organizacji działań. Kluczowe znaczenie ma tu zatem współpraca między organami UE a administracją państw członkowskich (stosunki wertykalne), a także pomiędzy organami administracji państw członkowskich (stosunki horyzontalne). Wiąże się to $\mathrm{z}$ powstaniem nowych struktur wymagających koordynacji ich działan ${ }^{31} \mathrm{i}$ kooperacji (europejskie sieci organów). Proces konwergencji wymusza przy tym ujednolicenie, uniformizację, na przykład w ramach powiązań sieciowych powoływanie subregulatora w ramach działań na rzecz spójności i rozwoju unijnego systemu kontroli wydatkowania środków publicznych opartych na monitoringu, sprawozdawczości, audycie, certyfikacji i odpowiednio działających w tych obszarach instytucji zarządzających, pośredniczących, komitetach sterujących itp.

Zmiany struktur administracji publicznej (w rozumieniu zarówno statycznym, jak i funkcjonalnym) nie są jednak wynikiem wyłącznie tendencji unijnych, lecz przemian zachodzących $\mathrm{w}$ wyniku określonych uwarunkowań wewnętrznych, powodowanych aktualną polityką państwa. Obserwując legislację w obrębie publicznego prawa gospodarczego, a w szczególności w obszarze, jakim jest rozwój przedsiębiorczości i jego wspieranie, należy postawić pytanie o rolę państwa w tym obszarze - czy podlega ona przeobrażeniu? W wypadku odpowiedzi twierdzącej w kontekście wcześniejszych spostrzeżeń oznaczałoby to zmianę zadań administracji (ich treści, zakresu), a w konsekwencji przebudowę bądź tworzenie nowych struktur administracji gospodarczej. Jest to jednak szerszy problem przeobrażeń struktur administracji publicznej w związku z określoną (w znaczeniu celową) polityką państwa.

Dla przykładu w Strategii na rzecz odpowiedzialnego rozwoju do roku 2020 polski rząd wśród kierunków interwencji wskazał „zwiększenie koordynacji wsparcia inwestycji rozwojowych". Ma to nastąpić przez wprowadzenie zmian instytucjonalnych ukierunkowanych na lepszą koordynację działań podmiotów realizujących politykę gospodarczą w zakresie wsparcia inwestycji rozwojowych, która ma służyć również eliminacji dublowania się ich kompetencji oraz zwięk-

31 K. Kokocińska, Koordynacja działań organów właściwych w sektorach infrastrukturalnych, [w:] Sektory infrastrukturalne - problematyka prawna, red. M. Królikowska-Olczak, Warszawa 2018, s. 65-79. 
szeniu ich efektywności poprzez łączenie poszczególnych funkcji ${ }^{32}$. W strategii zapowiedziane zostało utworzenie Polskiego Funduszu Rozwoju oraz Grupy PFR. Opierając się na tak sformułowanych założeniach polityki państwa, zasady funkcjonowania instytucji rozwoju oraz tryb współpracy między nimi w ramach „systemu instytucji rozwoju” zostały określone ustawą z dnia 4 lipca 2019 roku o systemie instytucji rozwoju ${ }^{33}$. Ustawa ta wskazuje także rolę Polskiego Funduszu Rozwoju Spółki Akcyjnej z siedzibą w Warszawie w systemie instytucji rozwoju oraz warunki finansowania przedsiębiorców przez Polski Fundusz Rozwoju. „System instytucji rozwoju” tworzą: Polski Fundusz Rozwoju, Bank Gospodarstwa Krajowego, Polska Agencja Rozwoju Przedsiębiorczości, Korporacja Ubezpieczeń Kredytów Eksportowych SA, Polska Agencja Inwestycji i Handlu S.A. oraz Agencja Rozwoju Przemysłu SA Są to struktury organizacyjne powołane do realizacji celów polityki gospodarczej rządu i rządowych programów gospodarczych, określane wspólnie w SOR jako tak zwana Grupa PFR. Z uzasadnienia do projektu ustawy o systemie instytucji rozwoju wynika, że

ma [ona] na celu uregulowanie zasad i wzmocnienie współpracy między głównymi instytucjami państwa realizującymi działania na rzecz rozwoju gospodarczego i społecznego, stosując instrumenty ekonomiczne, oraz przez inną obecność na rynku krajowym i rynkach zagranicznych. Realizacji powyższego celu będzie służyło przyjęcie mechanizmów zapewniających koordynację i wzajemne uzupehnianie się podmiotów $[\ldots]^{34}$.

„System” należy traktować jako zbiór, w którym da się wyodrębnić powiązane z sobą elementy, przy czym powiązania te mogą mieć różne źródło i odmienny charakter. Oznacza to, że powołanie struktury organizacyjnej określonej ustawowo jako „system” niesie z sobą określone konsekwencje prawne, zarówno w ujęciu strukturalnym (wzajemne powiązanie podmiotów wchodzących w skład sytemu, charakter relacji, zakres działania, treść zadań), jak i funkcjonalnym (istotą systemu jest jego funkcjonalność w znaczeniu 'sprawność, efektywność i skuteczność działania'). Struktury organizacyjne wchodzące w skład „systemu instytucji rozwoju”, określane jako „instytucje rozwoju”, realizują zadania z zakresu polityki gospodarczej rządu, głównie przez udzielanie wsparcia finansowego (choć nie wyłącznie ${ }^{35}$ ), podlegając nadzorowi (w tym właścicielskiemu)

32 SOR, s. 126.

33 Dz.U. z 2019 r. poz. 1572.

34 Uzasadnienie do projektu ustawy, druk sejmowy nr 3479, s. 1.

$35 \mathrm{Na}$ ten temat zob. m.in. B. Popowska, Agencje - nowe formy realizacji zadań administracyjnych państwa, [w:] Kierunki rozwoju prawa administracyjnego. Podstawowe zagadnienia prawa budowlanego i planowania przestrzennego. Dziesiate Niemiecko-Polskie Kolokwium Prawników Administratywistów Poznań, 8-12 września 1997 r. Referaty i głosy w dyskusji, red. H. Bauer et al., Poznań 1999, s. 207-217; J. Niczyporuk, Rzadowe agencje gospodarcze, [w:] Administracja i prawo administracyjne u progu trzeciego tysiaclecia. Materiały Konferencji Naukowej Katedr Prawa i Postępowania Administracyjnego, Lódź, wrzesień 2000 r., Łódź 2000; idem, Agencje rzqdowe, [w:] Prawo administracyjne ustrojowe. Podmioty administracji publicznej, red. J. Stelmasiak, J. Szreniawski, Bydgoszcz-Lublin 2002, s. 169; K. Kokocińska, A. Trela, Polska Agencja Rozwo- 
ministra właściwego do spraw gospodarki i ministra właściwego do spraw finansów publicznych. Instytucje rozwoju działają na odrębnych podstawach prawnych, w różnych formach organizacyjnoprawnych. Są to zarówno spółki akcyjne, państwowa osoba prawna oraz bank państwowy. Zdaniem projektodawcy

brak formalnoprawnej płaszczyzny dla stałej współpracy i koordynacji działań, czyli bez angażowania w bieżące sprawy ww. ministrów i obsługujących ich ministerstw [...] zmniejsza możliwości pełnego wykorzystania sumy potencjałów tych podmiotów, bowiem nie daje wystarczającej pewności prawnej przy podejmowaniu wspólnych inicjatyw. Wraz z rosnącym zaangażowaniem w nowe, bardziej zaawansowane przedsięwzięcia, obecna formuła współpracy tych podmiotów w naturalny sposób wyczerpuje swoje możliwości ${ }^{36}$.

Przyjęcie rozwiązań prawnych, których celem jest poprawa efektywności działania struktur aparatu państwa, wyznaczających w sposób jednoznaczny relacje między podmiotami powołanymi do realizacji zbliżonych zadań publicznych, jest pożądanym kierunkiem zmian. Racjonalność działań administracji publicznej i tak mocno podkreślana w doktrynie ich skuteczność wymagają spójnych rozwiązań instytucjonalnych, włącznie z koordynacją funkcjonowania wyodrębnionego aparatu gospodarczego — w tym wypadku ,instytucji rozwoju”. Tak daleko idące zmiany w zakresie zasad funkcjonowania administracji publicznej powinny jednak uwzględniać inne uwarunkowania niż tylko sprawność i efektywność działania, dotyczące aktywności struktur państwa, przede wszystkim uwarunkowania ustrojowe, zakładające funkcjonowanie układów zdecentralizowanych, które zarządzają rozwojem na poziomie regionalnym i lokalnym ${ }^{37}$. Tymczasem wskazane w ustawie instytucje rozwoju działają, opierając się na wspólnie wypracowanej strategii, która uwzględnia postanowienia przepisów odrębnych, dokumentów programów przyjętych przez Radę Ministrów lub właściwego ministra oraz dokumentów programowych instytucji rozwoju, a do której nie stosuje się przepisów ustawy o zasadach prowadzenia polityki rozwoju. Wyłącznie to ma charakter zasadniczy dla konstrukcji „systemu instytucji rozwoju”, albowiem wyklucza stosowanie mechanizmu prowadzenia polityki rozwoju jako zespołu wzajemnie powiązanych działań wszystkich podmiotów władzy wykonawczej, w tym jednostek samorządu terytorialnego ${ }^{38}$.

Charakter opracowania pozwala jedynie na przedstawienie pewnych uogólnień, które mogą prowokować do dalszych, pogłębionych badań nad zachodzący-

ju Przedsiębiorczości. Status prawny, „Prawo i Administracja” 4, 2005, s. 283-295; E. Kosiński, Realizacja zadań administracji gospodarczej $w$ formie rzadowych agencji gospodarczych. Status prawny agencji, „Kwartalnik Prawa Publicznego” 2008, nr 1-2, s. 7-49.

36 Uzasadnienie do projektu ustawy..., s. 2-3.

37 Zob. m.in. K. Kokocińska, Prawny mechanizm prowadzenia polityki rozwoju w zdecentralizowanych strukturach władzy publicznej, Poznań 2014; eadem, Zespót wzajemnie powiazanych działań jako kwalifikowana forma wspótpracy podmiotów władzy wykonawczej, [w:] Księga jubileuszowa Profesora Jana Jeżewskiego, red. A. Cudak, I.M. Szkotnicka, Warszawa 2018, s. 173-183.

38 K. Kokocińska, Decentralizacja jako ustrojowa zasada relacji pomiędzy organami władzy publicznej, RPEIS 2016, nr 2, s. 27-36. 
mi zmianami w obrębie struktur administracji publicznej. Zakres zmian i stopień uwzględnienia założeń systemowych odnoszących się do aktywności państwa w gospodarce wskazuje, że mamy do czynienia z tworzeniem resortowego schematu w zarządzaniu rozwoju, dla których to zmian uzasadnieniem jest potrzeba koordynacji działań. Przytoczony przykład wskazuje, że przy zachowaniu ciągłości struktur już funkcjonujących przeprowadzone zostały reorganizacja, przegrupowanie jednostek organizacyjnych, redystrybucja funkcji i źródeł finansowania.

\section{Wnioski}

W dokumentach programowych, aktach polityki państwa na rzecz rozwoju kraju podkreśla się konieczność podejmowania działań ukierunkowanych na rozwój gospodarki, w tym działalności gospodarczej, zobowiązując jednocześnie ustawą organy administracji publicznej do prowadzenia działań na rzecz wspierania przedsiębiorczości. W ustawie Prawo przedsiębiorców ustawodawca akcentuje potrzebę tworzenia możliwości do rozwoju działalności w warunkach wolnej konkurencji, kierując się konstytucyjną zasadą wolności gospodarczej, uwypuklając jednocześnie znaczenie i potrzebę ochrony oraz wspierania wolności działalności gospodarczej. Działania te mają przyczyniać się do rozwoju gospodarki oraz wzrostu dobrobytu społecznego.

Przyjęta polityka państwa na rzecz rozwoju wywołuje określone konsekwencje zarówno w sferze normatywnej, jak i funkcjonalnej. Obecnie najistotniejsze są jednak przeobrażenia zachodzące w strukturach administracji publicznej, które stanowią nieodłączny element przemian gospodarczych i społecznych. Trendem ogólnoświatowym jest ciągłe poszukiwanie nowych rozwiązań organizacyjnych i funkcjonalnych administracji publicznej, których zakładanym efektem ma być usprawnienie jej działania, budowanie administracji racjonalnej. Impulsem przemian w obrębie struktur administracji publicznej są cele polityki państwa (trwały rozwój kraju, osiąganie celów społecznych i gospodarczych wynikających z przyjmowanych dokumentów programowych), do których realizacji tworzone są lub modyfikowane dotychczasowe struktury aparatu państwa.

Dlatego zagadnienia strukturalne aparatu wykonawczego państwa są jednym $\mathrm{z}$ najistotniejszych zagadnień, które należy podkreślać $\mathrm{w}$ prowadzonych badaniach nad sprawnością funkcjonowania państwa, także z punktu widzenia procesu organizowania aparatu władzy wykonawczej w obszarze wspierania rozwoju przedsiębiorczości. Reorganizacja administracji publicznej stanowi wynik wdrażania polityki państwa na rzecz rozwoju. Jest to proces kształtowania modelu administracji pod hasłem administracji usprawnionej i udoskonalonej, odpowiedniej do społeczno-gospodarczych potrzeb (zgodnie z SOR) administracji działającej na rzecz wspierania przedsiębiorczości i jej rozwoju. 


\section{Bibliografia}

Bigo T., Prawo administracyjne. Część ogólna, Lwów 1932.

Churski P., Czynniki rozwoju regionalnego i polityka regionalna $w$ Polsce $w$ okresie integracji z Unią Europejska, Poznań 2008.

Fedorowicz M., Kilka uwag o zjawisku samoregulacji na rynku bankowym w nowej architekturze nadzorczej, „Studia Administracyjne Uniwersytetu Szczecińskiego” 2018, nr 10.

Hausner J., Zarządzanie publiczne, Warszawa 2008.

Izdebski H., Kulesza M., Administracja publiczna. Zagadnienia ogólne, Warszawa 2004.

Jeżewski J., Polityka administracyjna. Zagadnienia podstawowe, [w:] A. Błaś, J. Boć, J. Jeżewski, Administracja publiczna, red. J. Boć, Wrocław 2003.

Kokocińska K., Decentralizacja jako ustrojowa zasada relacji pomiędzy organami władzy publicz$n e j$, ,Ruch Prawniczy, Ekonomiczny i Socjologiczny” 2016, nr 2.

Kokocińska K., Istota aktów programowania rozwoju jako instrumentów oddziaływania państwa na gospodarke, [w:] Administracja a strategie i polityki publiczne, red. A. Jurkowska-Gomułka, Warszawa 2016.

Kokocińska K., Koordynacja działań organów właściwych w sektorach infrastrukturalnych, [w:] Sektory infrastrukturalne - problematyka prawna, red. M. Królikowska-Olczak, Warszawa 2018.

Kokocińska K., Prawny mechanizm prowadzenia polityki rozwoju $w$ zdecentralizowanych strukturach władzy publicznej, Poznań 2014.

Kokocińska K., Społeczna gospodarka rynkowa - komplementarność, równowaga czy przewaga wartości? Uwagi na tle działań państwa w zakresie prowadzenia polityki rozwoju, „Gdańskie Studia Prawnicze" 37, 2017.

Kokocińska K., Wspieranie rozwoju działalności gospodarczej w ujęciu zasad i wartości, „Ruch Prawniczy, Ekonomiczny i Socjologiczny” 2018, nr 4.

Kokocińska K., Zespót wzajemnie powiązanych działań jako kwalifikowana forma wspótpracy podmiotów władzy wykonawczej, [w:] Księga jubileuszowa Profesora Jana Jeżewskiego, red. A. Cudak, I.M. Szkotnicka, Warszawa 2018.

Kokocińska K., Trela A., Polska Agencja Rozwoju Przedsiębiorczości. Status prawny, „Prawo i Administracja" 4, 2005.

Kosiński E., Realizacja zadań administracji gospodarczej $w$ formie rzadowych agencji gospodarczych. Status prawny agencji, „Kwartalnik Prawa Publicznego” 2008, nr 1-2.

Kryzys prawa administracyjnego, t. 1. Jakość prawa administracyjnego, red. D.R. Kijowski, A. Miruć, A. Suławko-Karetko, Warszawa 2012.

Kryzys prawa administracyjnego, t. 2. Inflacja prawa administracyjnego, red. P.J. Suwaj, Warszawa 2012.

Kulesza M., Z problematyki badań nad metodami działania administracji, [w:] Zbiór studiów z zakresu nauk administracyjnych, red. Z. Rybicki, M. Gromadzka-Grzegorzewska, M. Wyrzykowski, Wrocław 1978.

Lipowicz I., Europeizacja administracji publicznej, „Ruch Prawniczy, Ekonomiczny i Socjologiczny" 2008, nr 1.

Niczyporuk J., Agencje rzadowe, [w:] Prawo administracyjne ustrojowe. Podmioty administracji publicznej, red. J. Stelmasiak, J. Szreniawski, Bydgoszcz-Lublin 2002.

Niczyporuk J., Rzadowe agencje gospodarcze, [w:] Administracja i prawo administracyjne u progu trzeciego tysiaclecia. Materiały Konferencji Naukowej Katedr Prawa i Postępowania Administracyjnego, Łódź, wrzesień 2000 r., Łódź 2000.

Popowska B., Agencje - nowe formy realizacji zadań administracyjnych państwa, [w:] Kierunki rozwoju prawa administracyjnego. Podstawowe zagadnienia prawa budowlanego i planowania przestrzennego. Dziesiate Niemiecko-Polskie Kolokwium Prawników Administratywistów

Prawo 329, 2020

(C) for this edition by CNS 
Poznań, 8-12 września 1997 r. Referaty i głosy w dyskusji, red. H. Bauer, R. Hendler, P. Huber, B. Popowska, T. Rabska, M. Szewczyk, Poznań 1999.

Rabska T., Działania administracji publicznej w świetle współczesnej koncepcji publicznego prawa gospodarczego, [w:] Instrumenty i formy prawne działania administracji gospodarczej, red. B. Popowska, K. Kokocińska, Poznań 2009.

Rydlewski G., Polityka i administracja w rządach państw członkowskich Unii Europejskiej, Warszawa 2006.

Strzyczkowski K., Uwagi o zadaniach nauki o prawnych formach działania administracji gospodarczej, [w:] Instrumenty i formy prawne dziatania administracji gospodarczej, red. B. Popowska, K. Kokocińska, Poznań 2009.

Suwaj P.J., Polityka publiczna jako instrument administrowania, [w:] Nauka administracji, red. B. Kudrycka, B.G. Peters, P.J. Suwaj, Warszawa 2009.

Suwaj P.J., Szczepankowski R., Wokół pojęcia polityki publicznej, [w:] Nauka administracji, red. B. Kudrycka, B.G. Peters, P.J. Suwaj, Warszawa 2009.

System Prawa Administracyjnego, red. R. Hauser, Z. Niewiadomski, A. Wróbel, t. 8a. Publiczne prawo gospodarcze, Warszawa 2018.

Trubek D.M., Corttel P., Nance M., ,Soft law”, „, hard law” and EU integration, [w:] New Governance and Constitutionalism, red. J. Scott, G. de Burca, Oxford 2005.

\title{
State involvement in enterprise development - a normative, functional, and structural perspective
}

\author{
Summary
}

There are two foremost reasons to address state involvement in enterprise development - an issue which most often tends to be analysed from the standpoint of functions of public administration in the economy - namely the intensity and the extent of the introduced changes. The aim of this study is thus to demonstrate that the policy the state adopts to promote development has particular ramifications, both for the normative and functional sphere, as well as - quite notably - for the structures of public administration. New organisational and functional solutions within public administration are implemented to streamline its activities and to build rational administration. Shaping a new model of administration or, alternatively, its reorganisation to arrive at structures which match social-economic needs, requires fundamental systemic premises to be taken into account.

Keywords: supporting enterprise development, function of the state in the economy, social-economic development, networked administration, development institutions. 